\title{
A Unique Case of Classic Kaposi's sarcoma restricted to the toes
}

\author{
Anne S. Renteria', Vickie A. Marshall ${ }^{2}$, Yanyu Sun ${ }^{3}$, Porselvi Chockalingam ${ }^{4}$, Jay S. Cooper ${ }^{4}$, \\ Yiwu Huang ${ }^{4}$, Denise Whitby ${ }^{2}$ \\ 1. Mount Sinai Medical Center, New York, NY 10029, USA; \\ 2. Viral Oncology Section, AIDS and Cancer Virus Program, SAIC-Frederick, NCI-Frederick, Frederick, MD 21702, USA; \\ 3. Department of Pathology, Maimonides Medical Center, Brooklyn, NY 11219, USA; \\ 4. Maimonides Cancer Center, Brooklyn, NY 11220, USA.
}

Corresponding author:

Anne S. Renteria

Mount Sinai Medical Center

One Gustave L. Levy Place, box 1410

New York, NY 10029, USA

E-mail:

anne.renteria@mountsinai.org

Key words:

China, KSHV, HIV, human herpesvirus-8 subtypes, Kaposi's sarcoma, viral phylogeny

\begin{abstract}
Background: Kaposi's sarcoma associated-herpesvirus causes all forms of Kaposi's sarcoma, and six major subtypes have been described based on the amino acid sequences of the open reading frame $\mathrm{K} 1$.

Main observations: A 71-year-old man from China, HIV negative, presented with nodules on the dorsal aspect of his toes. Biopsy confirmed the diagnosis of Kaposi's sarcoma and virology studies of his blood and saliva confirmed the presence of Kaposi's sarcoma associated-herpesvirus infection. Viral genotyping was consistent with subtype C3. Intervention has been deferred as our patient has remained clinically asymptomatic and without evident growth of his lesions over a 2-year follow up.
\end{abstract}

Conclusions: We herein report the first known case of Kaposi's sarcoma restricted to the toes caused by the viral subtype C3 in an HIV-negative patient from Harbin, China. (J Dermatol Case Rep. 2013; 7(3): 97-100)

\section{Introduction}

Kaposi's sarcoma associated-herpesvirus (KSHV), also known as human herpesvirus-8 (HHV-8), discovered in $1994,{ }^{1}$ causes all forms of Kaposi's sarcoma (KS), ${ }^{2,3}$ as well as primary effusion lymphoma ${ }^{4}$ and is associated with multicentric Castleman's disease. ${ }^{5} \mathrm{KS}$ is classified into four epidemiologic variants: Classic-KS, African-endemic KS, Iatrogenic-KS and AIDS-KS. The incidence of KS varies geographically reflecting variations in the prevalence of KSHV. ${ }^{6,7}$

$\mathrm{KSHV}$ is highly conserved overall but genes at both ends of the genome vary considerably. At the left-hand end is the open reading frame $\mathrm{K} 1$ (ORF-K1) gene which has been used for sub-typing. ${ }^{8}$ Six major subtypes (A,B,C,D,E and F) have been defined, together with further subdivisions into clades or subgroups (e.g. A1, A2, A3).$^{9,10}$ The distribution of different subtypes correlates with different ethnic and geographic populations, with the subtype $\mathrm{C}$ predominating across Asia. Herein we report a unique case of Classic-KS caused by a KSHV subtype C3 in a patient originally from northeast China.

\section{Case Report}

A 71-year-old man from Harbin, Heilongjiang, noticed a dark nodule on the fourth toe of his right foot for the past year. Being asymptomatic he initially did not seek medical advice. As new similar lesions developed next to the first one he sought medical evaluation and was managed (elsewhere) with laser ablation therapy. The lesions recurred three months later at the same site.

His past medical history was notable for recurrent onychomycosis of toenails for several years, coronary artery disease, hypertension, stroke with no neurological sequellae, pulmonary tuberculosis more than 30 years ago. He denied taking any immunosuppressants at any time. He moved in 1976 to the United States, and his parents were originally from Zhejiang. On physical examination he had three firm, smooth, purplish nodules on the dorsal aspect of his fourth right toe (Fig. 1A) and a 3.0-mm lesion on the tip of his second toe with no surrounding erythema or skin changes. No other similar skin lesions were noted anywhere else on the body. No popliteal or inguinal lymph nodes were palpable. 
A biopsy revealed changes suggestive of KS (staining for CD34, CD31), and KSHV latency associated nuclear antigen (Fig. 1B-E). Testing for HIV antibody by ELISA was negative. Intervention was considered but deferred in view of lack of symptoms, and the recommendation was watchful waiting with clinical follow-up.

With the approval of the Maimonides IRB, blood and saliva were analyzed at the Viral Oncology Section, NCI-Frederick. KSHV antibody detection against the lytic antigen K8.1 KSHV and the latent antigen ORF73 were performed as previously described ${ }^{11}$ and detected, confirming KSHV infection. DNA was extracted, viral load was determined by qPCR for KSHV-K6 gene and human ERV-3, and viral genotyping was determined by amplification and sequencing of the KSHV-K1 gene, all performed as previously reported. ${ }^{12,13}$ The tree shown in Figure 2 demonstrates that this patient's unique sequence, designated MAIMO, groups with previously published sequences categorized as C3.

\section{Discussion}

Classic-KS is a spindle-shaped cell malignancy of endothelial cell origin that has a more benign and indolent course, and the affected organs are mainly skin and rarely internal organs. ${ }^{14,15}$ It is typically described in older men of Mediterranean and Jewish descent. KS is generally rare among Asians, and information about its incidence and presentation in China is sparse except for the province of Xinjiang ${ }^{16,17}$ where the seroprevalence ranges from 12.5 to $48 \%{ }^{17,18}$ For the whole country the reported prevalence for KSHV is low, with rates below $10 \%$ in the general population. ${ }^{19,20}$ We are not aware of any seroprevalence or KSHV subtype studies in the region of Heilongjiang where Harbin is located, in northeastern part of China.

The differential diagnosis for nodular KS is broad and includes bacillary angiomatosis, pyogenic granuloma, other vascular tumors, fibrohistiocytic tumors, resolving dermal fasciitis, spindle cell melanoma, and several other spindle cell mesenchymal neoplasms ${ }^{21}$ therefore underscoring the importance of a thorough diagnostic work up. Different modalities of treatment for classic-KS are available depending on its presentation, extent, and immune status of the patient, ${ }^{15}$ but the optimal therapy is not yet established. ${ }^{22} \mathrm{Ob}$ servation is appropriate for immunocompetent asymptomatic patients with little progression over a long period of ti$\mathrm{me}$, and spontaneous regression has also been described.

\section{Conclusions}

Analysis of sequences from our HIV-negative patient with no history of immunosuppressive therapy showed a unique KSHV sub-type C3 sequence. Cases of classic-KS are rare in subjects born in China, and we herein report the first case, to our knowledge, in an apparently immunocompetent person from northeast China and with a unique C3 subtype. KS should be included in the differential diagnosis of suggestive skin lesions of HIV negative patients, even when from areas where the reported incidence is low.

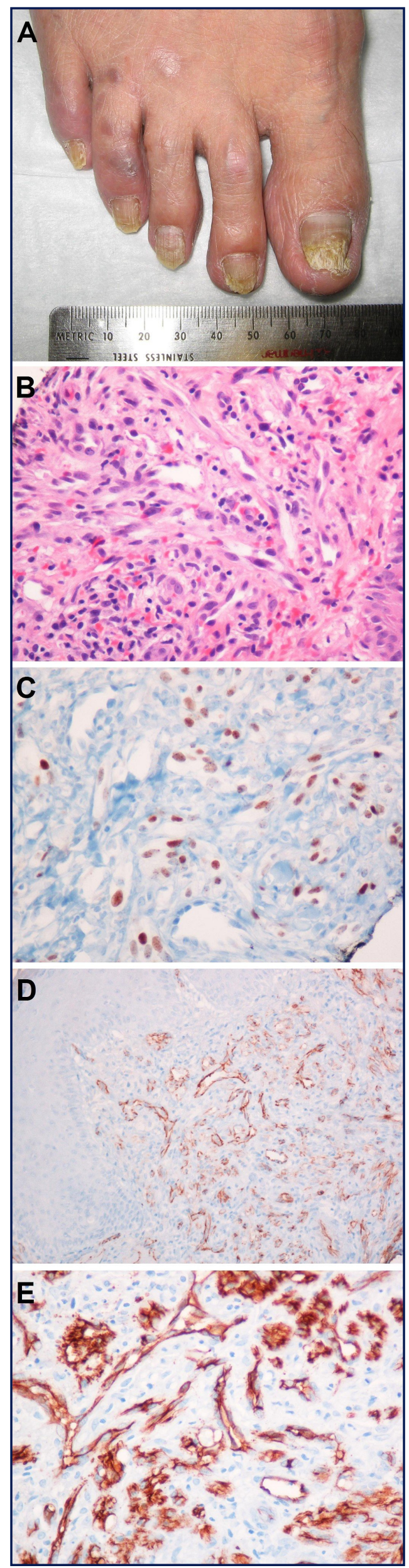

Figure 1

Cutaneous Kaposi's sarcoma.

(A) Purplishbrown nodules on the dorsal aspect of 4th toe.

(B) Spindle endothelial cells with mild atypia forming slits (H-E, X400).

(C-E) immunohistochemical stainings.

(C) HHV-8 nuclear staining (x400).

(D) CD31 endothelial cell cytoplasmic staining (x200).

(E) CD34 endothelial cell cytoplasmic staining (x400). 


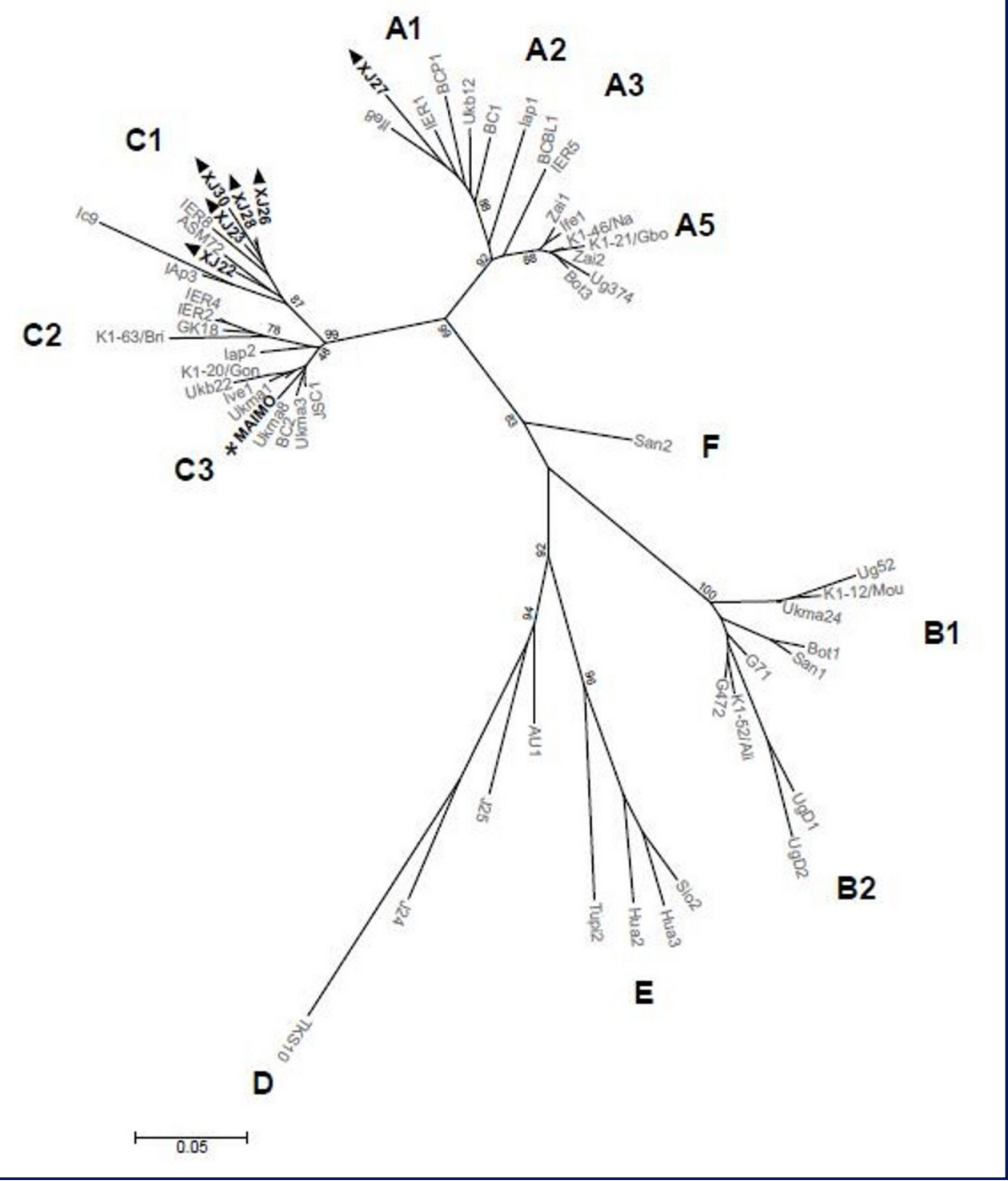

Figure 2

Phylogenetic Tree for MAIMO. Neighbor-joining amino acid analysis of the KSHV K1 gene. ${ }^{23}$ The phylogenetic tree contains 57 reference sequences obtained from GenBank, including 6 sequences published from Xinjiang, China indicated with $\boldsymbol{\Delta} .16$

The sequence from the current study is highlighted and designated "MAIMO.

\section{Acknowledgements}

This project has been funded in part with federal funds from the National Cancer Institute, National Institutes of Health, under contract N01-CO-12400.

\section{References}

1. Chang Y, Cesarman E, Pessin MS, Lee F, Culpepper J, Knowles DM, Moore PS. Identification of herpesvirus-like DNA sequences in AIDS-associated Kaposi's sarcoma. Science. 1994; 266: 1865-1869. PMID: 7997879.

2. Boshoff C, Whitby D, Hatziioannou T, Fisher C, van der Walt J, Hatzakis A, Weiss R, Schulz T. Kaposi's-sarcoma-associated herpesvirus in HIV-negative Kaposi's sarcoma. Lancet. 1995; 345: 1043-1044. PMID: 7723505.
3. Whitby D, Howard MR, Tenant-Flowers M, Brink NS, Copas A, Boshoff C, Hatzioannou T, Suggett FE, Aldam DM, Denton AS, et al. Detection of Kaposi sarcoma-associated herpesvirus in peripheral blood of HIV-infected individuals and progression to Kaposi's sarcoma. Lancet. 1995; 346: 799802. PMID: 7674745.

4. Cesarman E, Chang Y, Moore PS, Said JW, Knowles DM. Kaposi's sarcoma-associated herpesvirus-like DNA sequences in AIDS-related body-cavity-based lymphomas. N Engl J Med. 1995; 332: 1186-1191. PMID: 7700311.

5. Soulier J, Grollet L, Oksenhendler E, Cacoub P, Cazals-Hatem D, Babinet P, D'Agay MF, Clauvel JP, Raphael M, Degos L, et al. Kaposi's sarcoma-associated herpesvirus-like DNA sequences in multicentric Castleman's disease. Blood. 1995; 86: 1276-1280. PMID: 7632932.

6. Uldrick TS, Whitby D. Update on KSHV epidemiology, Kaposi Sarcoma pathogenesis, and treatment of Kaposi Sarcoma. Cancer Lett. 2011; 305: 150-162. PMID: 21377267.

7. deSanjose S, Mbisa G, Perez-Alvarez S, Benavente Y, Sukvirach S, Hieu NT, Shin HR, Anh PT, Thomas J, Lazcano E, Matos $E$, Herrero R, Muñoz N, Molano M, Franceschi S, Whitby D. Geographic variation in the prevalence of Kaposi-sarcomaassociated herpesvirus and risk factors for transmission. J Infect Dis. 2009; 199: 1449-1456. PMID: 19351262. 
8. Zong JC, Ciufo DM, Alcendor DJ, Wan X, Nicholas J, Browning PJ, Rady PS, Tyring SK, Orenstein JM, Rabkin CS, Su IJ, Powell KF, Croxson M, Foreman KE, Nickoloff BJ, Alkan S, Hayward GS. High-level variability in the ORF-K1 membrane protein gene at the left end of the Kaposi's sarcoma-associated herpesvirus genome defines four major virus subtypes and multiple variants or clades in different human populations. J Virol. 1999; 73: 4156-4170. PMID: 10196312.

9. Zong J, Ciufo DM, Viscidi R, Alagiozoglou L, Tyring S, Rady P, Orenstein J, Boto W, Kalumbuja H, Romano N, Melbye M, Kang GH, Boshoff C, Hayward GS. Genotypic analysis at multiple loci across Kaposi's sarcoma-herpesvirus (KSHV) DNA molecules: clustering patterns, novel variants and chimerism. J Clin Virol. 2002; 23: 119-148. PMID: 11595592.

10. Kajumbula H, Wallace RG, Zong JC, Hokello J, Sussman N, Simms S, Rockwell RF, Pozos R, Hayward GS, Boto W. Ugandan Kaposi's sarcoma-associated-herpesvirus phylogeny: evidence for cross-ethnic transmission of viral subtypes. Intervirology. 2006; 49: 133-143. PMID: 16428889.

11. Mbisa GL, Miley W, Gamache CJ, Gillette WK, Esposito D, Hopkins R, Busch MP, Schreiber GB, Little RF, Yarchoan R, Ortiz-Conde BA, Labò N, Whitby D. Detection of antibodies to Kaposi's sarcoma-associated herpesvirus: a new approach using K8.1 ELISA and a newly developed recombinant LANA ELISA. J Immunol Methods. 2010; 356: 39-46. PMID: 20211626.

12. Marshall V, Parks T, Bagni R, Wang CD, Samols MA, Hu J, Wyvil KM, Aleman K, Little RF, Yarchoan R, Renne R, Whitby D.Conservation of virally encoded microRNAs in Kaposi sarcoma-associated herpesvirus in primary effusion lymphoma cell lines and in patients with Kaposi sarcoma or multicentric Castleman disease. J Infect Dis. 2007; 195: 645-659. PMID: 17262705.

13. Mbulaiteye S, Marshall V, Bagni RK, Wang CD, Mbisa G, Bakaki PM, Owor AM, Ndugwa CM, Engels EA, KatongoleMbidde E, Biggar RJ, Whitby D. Molecular evidence for mother-to-child transmission of Kaposi sarcoma-associated herpesvirus in Uganda and K1 gene evolution within the host. J Infect Dis. 2006; 193: 1250-1257. PMID: 16586362.
14. Antman K, Chang Y. Kaposi's sarcoma. N Engl J Med. 2000; 342: 1027-1038. PMID: 10749966.

15. Schwartz RA, Micali G, Nasca MR, Scuderi L. Kaposi sarcoma: a continuing conundrum. J Am Acad Dermatol. 2008; 59: 179-206. PMID: 18638627.

16. Zhang D, Pu X, Wu W, Jin Y, Juhear M, Wu X. Genotypic analysis on the ORF-K1 gene of human herpesvirus-8 from patients with Kaposi's sarcoma in Xinjiang, China. J Genet Genomics. 2008; 35: 657-663. PMID: 19022199.

17. Dilnur P, Katano H, Wang ZH, Osakabe $Y$, Kudo M, Sata T, Ebilhara Y. Classic type of Kaposi's sarcoma and human herpesvirus 8 infection in Xinjiang, China. Pathol Int. 2001; 51: 845-852. PMID: 11844050.

18. Fu B, Sun F, Li B, Yang L, Zeng Y, Sun X, Xu F, Rayner S, Guadalupe M, Gao SJ, Wang L. Seroprevalence of Kaposi's sarcoma-associated herpesvirus and risk factors in Xinjiang, China. J Med Virol. 2009; 81: 1422-1431. PMID: 19551832.

19. Wang GQ, Xu H, Wang YK, Gao XH, Zhao Y, He C, Inoue N, Chen HD. Higher prevalence of human herpesvirus 8 DNA sequence and specific IgG antibodies in patients with pemphigus in China. J Am Acad Dermatol. 2005; 52(3 Pt 1): 460-467. PMID: 15761424.

20. Mei Q, Ming ZW, Ping YX, Hui JJ, Bin ZY, Hong $W$, Juan L, Zhe CY, Wei T, Han Y. HHV-8 seroprevalence in blood donors and HIV-positive individuals in Shandong area, China. J Infect. 2007; 55: 89-90. PMID: 17157915.

21. Radu O, Pantanowitz L. Kaposi sarcoma. Arch Pathol Lab Med. 2013; 137: 289-294. PMID: 23368874.

22. Régnier-Rosencher E, Guillot B, Dupin N. Treatments for classic Kaposi sarcoma: a systematic review of the literature. J Am Acad Dermatol. 2013; 68: 313-331. PMID: 22695100 .

23. Saitou N, Nei M. The neighbor-joining method: a new method for reconstructing pylogenetics trees. Mol Biol Evol. 1987; 4: 406-425. PMID: 3447015. 